\title{
MEMORIAL NO TEMPO DA PANDEMIA
}

\author{
Freddy Orlando Espinoza Cárdenas ${ }^{1}$
}

\begin{abstract}
RESUMO
Relatos de um estudante de pós-graduação, a maneira de cronograma biográfica, no tempo da epidemia do Covid-19 no Amazonas. Doutorando em Sociedade e Cultura na Amazônia, enquanto se preparava para sua Qualificação, ficou em quarentena por considerar-se em risco. Durante esse tempo a pandemia tornou-se, não só tema principal senão também comportamental, por causa da perigo da doença. A atitude diária exigia novas ações e decisões. A pandemia penetrava em todas os cantos da sociedade humana, deixava a sua marcas e suas pegadas, e Manaus não foi a exceção, novas formas e maneira se assumiriam, sobretudo no que se referia a profilaxia e assepsia na saúde pública: Máscaras, isolamento e distanciamento social, prevenções e atenções médicas, etc. As relações familiares, fraternas e laborais se complicaram e tornaram-se complexas, provocando novas formas de interação; a internet e os médios de comunicação foram essenciais para proceder nestes Tempos de Pandemia. Era consciente que a minha tese estava sendo atravessada por uma nova percepção e visão do mundo, daí que deveria intentar descrever e relatar este novo período da humanidade. Este texto busca construir uma pequena memória deste marco divisor que experimentamos hoje, através de enumeração de relatos à maneira de cronograma, da própria vivência do autor, apoiado por programas de TV e Facebook, Whatsapp, Instagram na internet, a fim de explicar como este tempo marcará nossas vidas para sempre.
\end{abstract}

\section{Palavras Chaves: Memória, Pandemia, Sociedade e Cultura}

\section{PANDEMIC TIME MEMORIAL}

\begin{abstract}
Reports of a graduate student, the way of biographical schedule, at the time of the Covid-19 epidemic in Amazonas. PhD student in Society and Culture in the Amazon, while preparing for his Qualification, he was quarantined for considering himself at risk. During that time, the pandemic became not only a main theme, but also a behavioral one, because of the danger of the disease. The daily attitude demanded new actions and decisions. The pandemic penetrated all corners of human society, left its marks and footprints, and Manaus was no exception, new forms and ways would be assumed, especially with regard to prophylaxis and asepsis in public health: Masks, isolation and social distance, preventions and medical attention, etc. Family, fraternal and work relationships became complicated and became complex, causing new forms of interaction; the internet and the media were essential to proceed in these Pandemic Times. I was aware that my thesis was being traversed by a new perception and view of the world, so I should try to describe and report this new period of humanity. This text seeks to build a small memory of this dividing mark that we experience today, through the enumeration of reports in the manner of a schedule, from the author's own experience, supported by TV programs and Facebook, Whatsapp, Instagram on the internet, in order to explain how this time will mark our lives forever.
\end{abstract}

\section{Keywords: memory, pandemic, society and culture}

\section{MEMORIAS EN LOS TIEMPOS DEL CORONAVÍRUS}




\begin{abstract}
RESUMEN
Memorias de un estudiante de posgrado, en estilo de cronograma biográfico, en tiempo del corona vírus Covid-19 en el Amazonas brasileño. Doctorando en Sociedad y Cultura em la Amazonía, em cuanto se preparaba para su Cualificación, estuvo en cuarentena por considerarlo en riesgo. Durante ese tiempo la pandemia se tornó, no sólo tema principal sino también de comportamiento, por causa del peligro de la enfermedad, la actitud diaria exigía nuevas acciones y decisiones. La pandemia se imiscuía en todas los rincones de la sociedad humana, y a su paso dejaba marcas y rastros, Manaus no fue la excepción, nuevas formas y maneras se asumirían, sobretodo en lo que se refería a la profilaxis y asepsia en la salud pública: Máscaras, aislamiento y distanciamiento social, prevenciones y atenciones médicas, etc. Las relaciones familiares, fraternas y laborales se complicaron y se tornaron complejas, provocándole nuevas formas de interacción; la internet y lo medios de comunicación fueron esenciales para proceder en estos Tiempos de Pandemia. Era consciente que mi tesis estaba siendo atravesada por una nueva percepción y visión del mundo, es por eso que debería intentar describir y relatar este nuevo período de la humanidad. Este texto busca construir una pequeña memoria del marco divisor que experimentamos hoy, a través de relatos al estilo de cronograma, de la propia vivencia del autor, ayudado por programas de TV, Facebook, Whatsapp, Instagram en la internet, a fin de explicar como este tiempo ha marcardo nuestras vidas para siempre.
\end{abstract}

\title{
Palabras Claves: Memoria, Pandemia, Sociedad y Cultura.
}

\section{Introdução}

Enquanto escrevia o Memorial para a minha Qualificação de Doutorado, instaurava-se, no país: O tempo da pandemia Covid-19. Todavia, para entender a minha abordagem biográfica acadêmica, que trato e quero sintetizar, acho conveniente relatar estes tempos difíceis que atravessa minha tese de doutorado. Para isso, tratarei de elaborar um cronograma do vírus no Amazonas, Brasil e na minha vida, daí que, elaborarei este relato a modo de diário, registrando o quadro em que vivi e sobrevivi a Pandemia pelo Covid - 19 na cidade de Manaus onde estava para tratativas do meu doutorado.

Para este autor diário é um instrumento onde registro as fontes vivas de minha pesquisa e para escrevê-lo segui a metodologia de abordagem autobiográfica e narrativa. Porque não acreditamos que a vida quotidiana possa ter só um ponto de vista objetivo senão que também a experiência do observador/pesquisador tem seus pressupostos, visões e percepções do período que vivemos em tempos de pandemia.

\section{Vivendo a Pandemia}

Eu me converti numa pessoa de risco, estava com 65 anos de vida. Havia vindo da Tríplice Fronteira a Manaus, para iniciar meu segundo ano de estudos no PPGSCA/UFAM. Cheguei no dia 9 de março de 2020. As aulas começariam dois dias depois de minha chegada. Tinha me matriculado na disciplina: Corpo e Sociedade e extensões no Amazonas, da professora Dra. Artêmis de Araújo Soares. Um dia após minha chegada, o vice-reitor da UFAM é diagnosticado com Covid-19. Na sexta feira, foram interrompidas as aulas da UFAM. A Prefeitura declara distanciamento social em Manaus. Um dia depois, a cidade já tinha uma vintena de infectados pelo vírus. Os Shoppings de Manaus fecharam as portas, dizendo que seria por 15 dias, os supermercados ficaram desabastecidos, mesmo assim, famílias inteiras, de 
medo, compraram o pouco que havia nas prateleiras. A praia e os motéis da Ponta Negra foram fechados por tempo indeterminado. O presidente Bolsonaro diz: "Depois da facada, não vai ser uma gripezinha que vai me derrubar”. Decreta cortar os salários pela metade para salvaguardar a economia do país. Um haitiano disse ao Bolsonaro: "Você não é presidente mais. Desiste! Você está espalhando vírus, vai matar brasileiros!". Em Lisboa, mais de uma centena de brasileiros lotaram o aeroporto, a fim de voltar para o Brasil. Enquanto isso, na TV e nas redes sociais, aparecem cisnes, peixes e golfinhos, nos canais límpidos de Veneza. Surge, na Bahia, o primeiro caso de indígena, suspeito de coronavírus. Os jornais noticiaram que "Uma pessoa morre a cada 10 minutos no Irã por coronavírus". Eduardo Bolsonaro culpa a China pelo coronavírus. Nas drogarias e nos supermercados não havia álcool gel e muito menos máscaras antissépticas. No dia 22 de março, Manaus tem a primeira morte de Covid-19, o empresário Geraldo Sávio, 49 anos.

$\mathrm{Na}$ manhã de terça-feira do 24 de março, uma leve brisa escarapelou minha pele. $\mathrm{O}$ jardim de dona Neuza (avó da minha filha, por parte de mãe) estava iluminado por um lindo céu azul. As húmidas rosas-cambraia ainda expelem seus aromas. $\mathrm{O}$ barulho dos escolares, da escola Castelo Branco, parecia mais feliz do que antes; os alunos voltavam para suas casas. O governo do Estado do Amazonas havia suspendido as aulas das escolas públicas e particulares. A passagem do equinócio de outono havia deixado a cidade mais entusiasmada, porque na Amazônia, ao contrário do que nos Estados Unidos e na Europa, a chegada de vento e chuva tornava o clima da floresta mais ameno. Alguns ficaram animados que o clima úmido e quente seria um obstáculo para contaminação do vírus. Esse dia, tínhamos meia dúzia de contaminados, a maioria deles, haviam sido contagiados em Miami e na Itália. No entanto, essa noite, as notícias da TV, anunciaram a primeira morte por Covid-19 no Amazonas. No dia seguinte, a maioria dos pastores das igrejas evangélicas pediam dinheiro pela internet a fim de orar pelo fim da pandemia. A bancada evangélica do Congresso pedia a Bolsonaro para reabrir os templos evangélicos com o intuito de "enfrentar essa pandemia maligna".

Quando percebi que respirava um cheiro de enxofre com sabor de água sulfurosa sabia que meu corpo expelia o ranço do vírus estranho. Já o havia pressentido na fronteira, no fím do ano passado, mas não the havia dado importância, achei que era os rumores próprios da cidade fronteiriça. A primeira coisa que fiz foi orar a nosso Deus. Era o mais sensato. Não sabíamos quase nada do Covid-19. Líamos os Salmos; os momentos mais difíceis da vida do rei David. Fazia uma semana que a mãe de meus filhos, Maria Nildeth, havia perecido por insuficiência 
respiratória, na verdade, todos seus órgãos vitais foram apagando-se pela disseminação do câncer.

As primeiras noites foram de muita insônia, eu tratava de dormir, buscava ser leve a fim de conciliar o sono, porém mais ansiedade produzia em mim devido às notícias da TV, que eram muito deprimentes e tristes. Não sei como se inteiraram meus amigos e familiares. Enviavam-me mensagens perguntando pela minha saúde. Talvez, como estava morando em Manaus, estavam preocupados comigo. É claro, nunca lhes disse que havia contraído o vírus. Tratava de mostrar serenidade e paz a meus filhos Karito e Nikolai e aos meus enteados Hélder, Hellen e sua mãe Vera Lúcia. Tinha muito medo de que meu corpo, de um momento a outro, tivesse tomado por uma tempestade de horror que produzia esta pandemia nas vidas dos infectados. Só a cadelinha Yorkshire e o gato Lacan, da minha enteada, notavam meu pavor e receio deste inesperado mal global. Por isso, eles dormiam ao meu lado, acredito eu, para mostrar sua proteção e vigiar meu sono. Dona Vera, seus dois filhos, e eu, estávamos infectados pelo Covid-19. Decidimos ficar em casa, tratar-nos, nós mesmos, com antibióticos e descongestionante, vitaminas e chás caseiros. Tomava o sol da manhã para meus ossos e pulmões, comia frutas e verduras, tomava muita água e vitaminadas. Chupava pastilhas Valda de menta, eucalipto e timol. Ungia-me de unguento Vick VapoRup, para meu peito e minhas articulações. Fiquei trancado na casa que era muito espaçosa e cômoda, com jardim e pátio refrescantes. Já temos passado mais de 70 dias. Amanhã, farei um teste de RNA para saber se ainda convivo com o vírus. Acho que a minha saúde ficou muito precária, sobretudo nas minhas articulações e no meu sistema cardiovascular. Minhas orações, continuam, mas peço a Deus, vida para terminar de escrever minha tese de doutorado, construir minha casa frente ao rio Solimões, e viajar pelo Meio Oriente.

Nesse dia, o número de infectados do Covid-19, em todos os estados do Brasil, era 1.620 casos. E o número de vítimas pelo coronavírus era de 25 mortos. O governo proíbe a entrada de estrangeiros da China, e da Europa, menos dos Estados Unidos, o país que tem mais mortos de Covid-19. No outro dia, os casos haviam-se multiplicado para 2.201 infectados de coronavírus e havia subido vertiginosamente para 47 mortes. Nos 26 estados do Brasil era: Rio de Janeiro - 305 infectados; Minas Gerais - 130; Espírito Santo - 33; Goiás - 27; Mato Grosso do Sul - 23; Mato Grosso - 7; Rio Grande do Sul - 98; Paraná - 65; Santa Catarina - 107; Pernambuco - 42; Ceará - 182; Sergipe - 15; Bahia - 76; Paraíba - 3; Maranhão - 8; Piauí 6; Alagoas - 7; Rondônia - 3; Tocantins - 7; Pará - 5; Amazonas - 47; Amapá - 1; Roraima 2; Acre - 17; e no Distrito Federal -160. Na noite desse dia, o presidente Jair Bolsonaro critica 
ferozmente o distanciamento social, alegando que assim iriam destruir a economia do país. Bolsonaro culpou à Globo por espalhar medo e pavor, falando que só se trataria de uma "gripezinha". Achamos que nesse dia, a projeção, do vírus, de Bolsonaro foi uma escolha política, e, eu arriscaria que nesse fatídico dia, instaurou-se uma estratégia de genocídio, na população mais pobre do Brasil, chamados de "invisíveis".

Na quarta-feira 25 de março de 2020, o ministro Mandetta anuncia a distribuição de cloroquina para pacientes do SUS em estado grave do Covid-19. Imediatamente, o professor Marcus Barros, ex-reitor da UFAM, adverte que uso indiscriminado desse remédio pode trazer consequências trágicas para quem sofre do coração, além de trazer outras sequelas que poderiam prejudicar a saúde do paciente de covid-19. O protocolo para manejo de corpo morto por causa do coronavírus: Os falecidos devem ser cremados ou sepultados, não podem velar o corpo senão ser enterrados imediatamente, com só 3 acompanhantes, que devem estar afastados a 3 metros, o caixão não pode ser aberto por hipótese nenhuma. Lembro, que, dias depois, no cemitério geral, um padre católico estava na entrada espalhando água benta aos centos de mortos diários em Manaus. Na sexta-feira, mais uma desfaçatez; Bolsonaro decreta que os cultos evangélicos e as missas religiosas devam ser considerados essenciais para o país. Mas, os prefeitos das cidades do Brasil têm a última palavra. Eles decretaram o distanciamento social, com exceção dos serviços essenciais, e, a maioria deles, não considera as igrejas nem templos religiosos como essenciais. Pela aquela época, a Coreia do Sul sentenciou um pastor fundamentalista, por abrir a sua igreja em tempos de pandemia, dessa forma, houve o contágio do vírus a mais de 4.000 mil membros. No sábado, o Jornal Nacional noticia que Brasil, segundo um estudo científico, poderia ter, no mês de julho, mais de um milhão de mortos de Covid-19. No entanto, passar-se-ia de dois milhões de contagiados de coronavírus e quase 100 mil mortos, números oficiais (não se levam em conta os números subestimados que podem elevar de 4 a 10 vezes mais as vítimas de Covid-19).

No dia 30 de março de 2020, chega ao Brasil as primeiras 500 mil unidades de testes rápidos, doados ao Ministério da Saúde. Os testes foram usados em profissionais de saúde e segurança com sintomas da covid-19. Infelizmente, estes testes não são confiáveis, eles somente garantem $40 \%$ de certeza. É iniciada a distribuição da terceira remessa de Equipamentos de Proteção Individual (EPIs) para profissionais de saúde que atendem pacientes com novo coronavírus. A distribuição totaliza 40 milhões de itens adquiridos para serem repassados aos estados e municípios. Mas estes kits não chegaram a todas as cidades nem hospitais do Brasil. 
No dia 31 de março de 2020, é confirmado o segundo óbito no Amazonas. Nesse dia, o presidente dos Estados Unidos, Donald Trump, revela possibilidade de banir voos provenientes do Brasil. O motivo é a postura do presidente Jair Bolsonaro diante das medidas restritivas de enfrentamento à pandemia. "O Brasil não tinha nenhum problema até pouco tempo atrás, e agora eles estão começando a ficar inflamados", disse Trump. A imprensa dos médios de comunicação satiriza o presidente do Brasil pela sua estreita amizade de "I'm Love Trump". Secretarias estaduais de Saúde terminam o dia com 5.812 casos confirmados de coronavírus. O Governo do Amazonas registra terceiro óbito decorrente da doença, em todo o país, número de cadáveres chega a 202. Eu, e a minha família de Manaus, nunca havíamos passado uma quarentena. Passar todo o dia em casa, no início foi leve. Lia um livro, assistia um filme, conversava com meus filhos (enteados), cozinhava, limpava, regava as plantas e alimentava aos gatos e cachorros da casa, Lacan; Luna; Lalinha e Mity. Assistia os noticiários e alguns programas culturais da TV. Na segunda semana de quarentena, comecei a quebrar o hábito que havia desenhado, porque havia-se tornado rotineira.

Foi assim que, por influência da minha enteada maior, comecei a presenciar um programa de reality: BBB2020. O programa já estava no seu último mês. Me chamou atenção que havia só um homem concorrendo contra sete mulheres, além disso, ele era preto, gordo, e era o mais velho delas. O participante somente queria ganhar apenas o carro. $\mathrm{O}$ ator Babu Santana já havia passado por mais de 5 paredões, apesar de parecer agoniado, mostrava-se sereno e sagaz. Tinha um bom discurso. Como era preto, e, eram brancas, quase todas a suas concorrentes, se presentou a oportunidade de mostrar, didaticamente, a estrutura do racismo no Brasil. Pouco a pouco, foi ganhando o respeito e carinho de todos nós. Foi assim, que eu e minha filha Hellen, assistíamos juntos as últimas semanas do programa de reality. Como fiéis expectadores, torcíamos e prevíamos quem seriam os próximos detonados e quem seria o ganhador. Foi assim que passou o mês de março 2020.

No dia $1^{\circ}$ de abril de 2020, a vítima mais jovem do Brasil é um homem de 23 anos, do Rio Grande do Norte. Até agora, muitos pensavam que só os idosos eram os mais propensos a óbito. Estudantes de medicina, enfermagem, fisioterapia e farmácia, de todas as universidades do país, são convocados para atuar no enfrentamento ao novo coronavírus. O programa "O Brasil conta comigo" estabelece carga horária de $20 \mathrm{~h}$ e $40 \mathrm{~h}$, com remunerações de R $\$ 522,50$ a R\$ $1.045,00$, respectivamente. Os estudantes também receberiam $10 \%$ de pontuação no ingresso em programa de Residência do Ministério da Saúde. Lamentavelmente, esses 
estudantes, na sua grande maioria, não receberam o seu ordenado, o que implicou em protestos em vários hospitais do Brasil.

O número de óbitos, nesse dia, foi atualizado e chegou a 241. São Paulo tem situação mais preocupante, com 2.981 casos confirmados da doença e 164 mortes. Por outro lado, todos os estados do Brasil têm casos confirmados e mais 19 registram mortes: Amazonas (3), Pará (1), Rondônia (1), Alagoas (1), Bahia (2), Ceará (8), Maranhão (1), Paraíba (1), Pernambuco (8), Piauí (4), Rio Grande do Norte (2), Minas Gerais (3), Rio de Janeiro (28), Distrito Federal (3), Goiás (1), Mato Grosso do Sul (1), Paraná (3), Rio Grande do Sul (4) e Santa Catarina (2). À noite, Amazonas confirma duas novas mortes, entre esses uma professora de música da UEA, e Ceará chega ao total de 21.

No dia 03 de abril de 2020, o governo federal anuncia R \$ 9,4 bilhões para fortalecer a rede pública de saúde no enfrentamento ao novo coronavírus. Os recursos seriam destinados à aquisição de novos testes de diagnóstico, medicamentos e equipamento hospitalares, como monitores de sinais vitais e ventiladores pulmonares. Desgraçadamente, até agora o Ministério da Saúde, gastou menos de 40\% desse orçamento. Além disso, a ajuda do Ministério é parcial, por exemplo, enviaram teste RT-PCR, mas sem os reagentes para análise e nem os cotonetes para colher a amostra nas vias respiratórias. O boletim do Ministério da Saúde aponta que Distrito Federal, São Paulo, Ceará, Rio de Janeiro e Amazonas podem estar em transição para a fase de aceleração descontrolada do coronavírus. A sexta-feira termina com 9.216 casos confirmados do novo coronavírus. O número de falecidos chega a 365 . Deus os abençoe e console a suas famílias. Os dados são das secretarias estaduais de saúde. Apenas três estados não registram óbitos até então: Acre, Amapá e Tocantins.

No dia 06 de abril de 2020, a semana começa com 11.298 casos do novo coronavírus e 489 finados decorrentes da doença, esses dados são das secretarias estaduais de saúde. Informações de bastidores indicam que o presidente Jair Bolsonaro cogita exonerar o ministro da Saúde, Luiz Henrique Mandetta, já que este não adere aos "palpites" contra a distensão social, ao uso da hidroxicloroquina, nem a divulgação diária dos “desaparecidos" por Covid19. No entanto, o ministro tinha o apoio dos presidentes das Câmaras de deputados e senadores, além das mídias e redes sociais. Mesmo assim, o presidente Bolsonaro decreta a saída do Distanciamento Social Ampliado (DAS) para o Distanciamento Social Seletivo (DSS). O objetivo é promover o retorno gradual das atividades laborais. O Ministério da Saúde atualiza dados no final da tarde: sobe para 12.056 o número de casos de Covid-19 no Brasil; aumenta 
para 553 o número de óbitos. Acre registra o primeiro óbito e apenas Tocantins não tem mortes por decorrência do novo coronavírus.

Quinta-feira, 09 de abril de 2020, o dia começa com 16.238 casos confirmados do novo coronavírus, segundo dados das secretarias estaduais de Saúde. O número de óbitos por Covid19 chega a 824. Com 23 casos, Tocantins segue como único estado que não registrou mortes. O Ministério da Saúde, publica uma portaria que libera mais de R 4 bilhões para estados e municípios. Os recursos devem ser utilizados para aquisição de materiais e insumos médicos, abertura de leitos e custeio de profissionais de saúde. O Brasil tem novo recorde referente à doença. Em 24 horas, foram registradas mais 141 mortes e 1.930 novos casos. O maior número de óbitos registrados em 24 horas havia sido contabilizado no boletim anterior, quando foram registradas 133 mortes.

Na sexta-feira, 10 de abril de 2020, é confirmada a morte de adolescente indígena, da etnia Yanomami, Alvanei Xirixana, de 15 anos. Ele estava internado na UTI do Hospital Geral de Roraima (HGR) desde o dia 3 de abril. É a primeira morte de um indígena decorrente do Covid-19 no estado. Os indígenas da Amazônia, através de seus caciques, advertem sobre a tragédia que será esta pandemia se o governo de Bolsonaro continuar esquecendo de políticas públicas para os territórios indígenas. Nesse dia, o hospital Delphina Aziz, referência no tratamento do novo coronavírus em Manaus (AM), entra em colapso. Perda de capacidade operacional é motivada pela falta de profissionais para atuar na linha de frente ao combate do novo coronavírus. Porém, os amazonenses, iguais a toda a humanidade, não acreditam em pandemias. Que isso, acontecia em outras culturas, distantes da sua cidade. Para eles, a pandemia era irreal, é um pesadelo que passa; quando a gente acorda! Que a pandemia não chegaria a sua região. Como é isso? Que por causa da pandemia deveríamos fechar nossos comércios, nosso mercado, nossos shoppings, nossas igrejas e escolas e ficar isolados, e suprimir o futuro diário de Zona Franca de Manaus; isso seria um caos! Não! Somos livres e superiores a qualquer pandemia! Mas, a gente é igual aos americanos, aos ingleses, aos franceses e italianos; nada humildes!

No dia 12 de abril, o Ministro da Saúde, Luiz Henrique Mandetta, disse em entrevista ao programa 'Fantástico' (TV Globo) que os meses de maio e junho seriam "mais duros” para as cidades, como Manaus. Critica, dissimuladamente, a atitude de Jair Bolsonaro com relação à pandemia. Ele diz que, "A flexibilização das medidas restritivas de maneira precoce pode levar ao padrão do início da epidemia no Brasil, com surgimento de surtos". O balanço oficial do Ministério da Saúde contabiliza 23.430 casos confirmados e 1.328 mortes por causa da 
Covid-19. Mas, as secretarias de Saúde dos estados terminam a noite com 23.753 casos e 1.355 óbitos. A recomendação do Ministério de Saúde era quarentena para as pessoas de alto risco, distanciamento dos cidadãos, lockdown nas cidades com mais incidência de contágio. Recomendava máscaras, lavar as mãos e usar álcool gel para limpar as superfícies de partículas do vírus que se tenha impregnado no celular, corrimão, no painel do ascensor etc. Porém, essa intempestiva pandemia tinha obrigado a todos os manauaras a comprar máscaras e álcool gel, e comida para a quarentena e os preços aumentaram excessivamente. A cartela de ovos chegou a custar 20 reais!

Terça-feira, 14 de abril de 2020, a pesquisa do Centro de Epidemiologia da Universidade Federal de Pelotas (UFPel) mede o nível de imunização da população ao coronavírus. Cerca de 33 mil pessoas de 133 municípios brasileiros devem ser submetidas ao teste rápido que detecta a presença de anticorpos IgM (infecção mais recente) e IgC (infecção mais antiga). Tocantins registra primeira morte por Covid-19. A vítima trabalhava na Secretaria Municipal de Saúde de Palmas e estava internada desde o dia 18 de março, na UTI de um hospital particular. Com isso, todos os estados do país têm óbitos decorrentes devido à Covid-19. O número de óbitos por coronavírus chega a 1.552 no Brasil. O país alcança novo recorde ao registrar 204 mortes em 24 horas. O total de casos confirmados de Covid-19 é 25.684. Medidas de ação social foram implantadas, compraram-se respiradores, máscaras e testes de covid-19 a preços exorbitantes. Fecharam bares, restaurantes, academias e ginásios, salões de beleza, boutiques e igrejas evangélicas. Mas, os inescrupulosos de sempre, aproveitaram para roubar os cofres públicos e à classe trabalhadora. Despidos massivos e sem justa causa, o governo que tinha determinado por lei estes abusos, e ninguém reclamou! Pelo contrário, uma carreata de carrões e caminhões de som (estimulados pelo Presidente capitão) assaltaram as avenidas da estrada Ponta Negra e do centro demandando ao governo estadual pela abertura do comércio e da economia do Estado do Amazonas. O governo já havia liberado 2 trilhões de reais aos bancos do país. Na realidade, passaram vários dias para dar-nos conta da realidade que estávamos atravessando, em que nos encontrávamos numa situação de colapso, não havia dinheiro, não havia leito nos hospitais, os caixões haviam-se esgotado e as vagas de túmulos haviam-se extrapolados.

No dia 16 de abril de 2020, completa um mês da primeira morte pelo novo coronavírus no Brasil. A vítima era um homem de 62 anos que estava internado num hospital da Rede Prevent Sênior, em São Paulo. Desde então, o número de óbitos chegou a 1.952. O Presidente da República, Jair Bolsonaro, decide exonerar o ministro da Saúde, Luiz Henrique Mandetta. Quem assume o ministério é o médico oncologista e empresário Nelson Teich. Esta decisão do 
presidente, causa reação nas principais capitais do país, gritos e protestos: "Fora Bolsonaro", o panelaço chegou até nos bairros de Manaus.

Segunda-feira, 20 de abril de 2020, Tocantins registra sua segunda morte, cerca de uma semana depois da primeira. O empresário de 68 anos estava internado em um hospital particular de Goiânia. O governo do estado afirmou que o caso foi registrado no município, Paraíso do Tocantins, de origem do paciente. É, esta forma de registrar os casos de contágio e óbitos do Covid-19. Mais tarde, era previsto que iria causar confusão, em relação a leitura real dos números da pandemia. O Ministério da Saúde anuncia a compra de mais 3,3 mil respiradores de uma empresa brasileira. Com a aquisição, passa para 14,1 mil o total de respiradores/ventiladores pulmonares adquiridos para a rede pública de saúde para enfrentar a pandemia do novo coronavírus. Porém, as compras de ventiladores e outros equipamentos contra a doença causou uma série de operações da Polícia Federal contra governos estaduais. No Amazonas, resultou a prisão da secretaria de saúde. O balanço do Ministério de Saúde registra 1.927 novos casos de Covid-19 e 113 mortes em 24 horas. Sobe para 40.581 o número de diagnósticos de coronavírus, e para 2.575 o número de óbitos. Secretarias de Saúde chegam à noite com 40.814 casos de coronavírus e 2.588 mortes.

Quinta-feira, 23 de abril de 2020, o Brasil batem novo recorde e registra 407 mortes por causa do novo coronavírus em 24 horas. O maior número de óbitos registrados em um dia era 217. Também atingiu recorde o número de casos confirmados no mesmo período: são 3.735 pessoas diagnosticadas com a doença. O maior número era, até então, 3.257. O Ministro da Saúde, Nelson Teich, diz não ser possível interpretar os dados e concluir se há indicativo de avanço da doença ou de diagnósticos médicos. Para ele, o foco é "ter ações", mas não detalha o que pensa. Este ministro não tem o carisma doutro, e, indiretamente, havia-se pronunciado que na decisão entre escolher um paciente jovem e outro idoso, ele optaria pelo adulto. Nesse dia, as secretarias de Saúde dos estados somam 50.036 casos do novo coronavírus. O mesmo levantamento registra 3.331 pessoas mortas por causa da contaminação. A gente contaminada já não queria ir ao hospital, porque além de proibir a entrada dos familiares, corria-se o risco de sair mortos e, aí, os familiares seriam impedidos de ir a seu sepultamento, somente duas pessoas da família poderiam enterrar seu morto. Graças a Deus, Manaus ainda não tinha forno de cremação, do contrário, os mortos por COVID-19 poderiam ser incinerados, que o protocolo da pandemia impôs. Havia nos hospitais caminhões frigoríficos, e até nos corredores se empilhavam os mortos, imagino a maioria dos corpos transferido do hospital ao forno de cremação, sem a necessidade de um caixão. A cidade, em menos de duas semanas, já tinha mais 
de mil mortos. Muitos desses havia morrido nas suas casas. Nós assistíamos pela TV a tragédia da pandemia que acontecia não muito distante de nossas casas. Não aguantamos, e acompanhamos o choro dessas famílias que haviam perdido sua mãe, filha, amigo e que mal compreendiam essa pandemia e só atinavam dizer que "fiquem nas suas casas" que se é necessário sair; "use máscara”. Havia também aspectos patéticos da pandemia, um caso que um “cidadão" foi à padaria comprar pão, porém sem máscara e o funcionário exigiu que usasse a máscara, o cliente, de 30 e poucos anos, puxou a arma que levava e lhe disparou, mas o tiro acertou numa cliente, empregada doméstica do bairro Vieiralves. Esse dia, pedi a meu filho, para que comprasse mais pastilhas de menta Valda, mas, havia desaparecido das prateleiras, muitas pessoas acreditavam que elas poderiam fazer bem aos pulmões.

A final do reality show se postergou para a segunda-feira, dia 27 de abril, a Globo não tinha mais como esticar o programa. A Rede Globo havia suspendido todas as suas novelas, consideradas de alto índice de audiência. O único programa que ainda rendia lucro para a emissora era o reality BBB. A importância do BBB20 servia de distração e desafogo do que estava ocorrendo no país com a pandemia Covid-19.

Terça-feira, 28 de abril de 2020, quase 200 brasileiros se inscrevem na plataforma 1 Day Sooner, que convoca pessoas para participar de testes de vacina para o coronavírus. Os voluntários são infectados de propósito com o vírus para que se possa testar diversos tipos de vacina ao mesmo tempo. A Agência Nacional de Vigilância Sanitária (Anvisa) aprova a realização de testes rápidos de Covid-19 em farmácias e drogarias. Até então, os exames de diagnóstico do novo coronavírus eram feitos apenas em hospitais e clínicas. A medida é válida até que dure a situação de emergência de saúde pública nacional. Passa de 5 mil o número de pessoas mortas pelo novo coronavírus no Brasil. Em 24 horas, foram registrados 474 novos óbitos, chegando a 5.017. No mesmo período, foram confirmados mais 5.385 casos, totalizando 71.886 diagnósticos. Estes números tristes da pandemia me levanta uma pergunta: Acredita-se em deus? Um Deus todo-poderoso que poderia curar aos homens e mulheres desta Pandemia. Mas, é muito difícil acreditar num Deus que cura alguns e deixe morrer a muitos outros. Mas em realidade, eram muito mais os que se curavam que os que morriam de Covid-19, um por cento.

Contudo, na noite anterior, o programa de reality exibiu a final do BBB2020. Provocou uma reação de audiência brasileira, mais de cem milhões de brasileiros assistiram a TV. A ganhadora da final do BBB2020 foi a médica Telma. O "pão e circo", da TV Globo, tornou-se uma caixa de ressonância dos males que o país sofre. O programa de reality show foi um reflexo 
de nossa sociedade. Expondo o ridículo governo de Bolsonaro contra a sociedade brasileira. A masculinidade tóxica é exposta e derrotada por um grupo de mulheres e um preto, aparentemente fraco e frágeis, porém com uma coragem insuspeitável, e, que de certa forma, atingiu o governo prepotente do autoritarismo ególatra de Bolsonaro. No final do programa, o debate do racismo; a exposição de suas vísceras e a lânguida estrutura da sociedade brasileira.

Quinta-feira, 30 de abril de 2020. O ministro da saúde, Nelson Teich, afirma que o número de mortes será determinante para o relaxamento das medidas de distanciamento social. No entanto, dias depois, o presidente Bolsonaro decreta que ginásios e salões de beleza são serviços essenciais durante a pandemia e, que por isso: "Podem estar abertos". Seria a gota para que o ministro Teich renunciara. O Ministério de Saúde registra 5.901 óbitos por coronavírus, e 85.380 casos de Covid-19.

A justiça decreta lockdown no Maranhão. Estarão em bloqueio total por dez dias, a partir de 05 de maio, a capital São Luís, e as cidades São José de Ribamar, Paço do Lumiar e Raposa. Os dados colocam o Brasil com mais casos confirmados do que a China, onde a epidemia começou. Outra marca: estudo do Imperial College London aponta que o país terá a maior taxa de contágio da Covid-19 no mundo.

Às vezes, acordo de madrugada, e, sinto o fedor do vírus no pútrido ar de Manaus, sinto que me sufoco. Trêmulo meu corpo, somente atino a orar, ou mais bem dito, a dialogar comigo mesmo. Assim minha angústia e depressão dissipa-se. Pouco a pouco, restabelece minha serenidade. Preparo meu café e tomo minhas vitaminas e remédio para minha pressão arterial. Era necessário ter paciência, esperar que acabe a quarentena, e a pandemia. Foi assim, que já passaram 70 dias, desde o início de março a finais de maio de 2020. No início de julho, a cidade de Manaus, "Graças a Deus", começou a diminuir as mortes por Covid-19. Os hospitais registraram menos infectados, os leitos de UTI vão desocupando-se. Foi muita alegria quando a notícia da TV registrou dois dias sem mortes. Alguns, diziam que o rebanho se havia criado, outros que o vírus havia mutado, havia os que acreditavam na eficiência dos médicos e enfermeiros, e da própria população de seguir à risca os protocolos de prevenção. Mais, os místicos, acreditavam no secreto da oração.

Infelizmente, no interior do Amazonas, a curva estava em ascensão. Tabatinga, Manacapuru, Parintins, Tefé e São Gabriel da Cachoeira, aumentavam os casos de infecção, mas uma centena de mortos, sobretudo os indígenas e os ribeirinhos. O desespero destes era grande, a situação era e continua precária. O medo os aterrorizava e se entregavam com 
estoicismo esperando a morte de seus velhos e anciões da comunidade bora, kokama, yanomami, munduruku, marubo, kanamari e tikuna.

Todavia, em Manaus, os sobreviventes da pandemia, pouco a pouco, pelos índices da diminuição da pandemia, esqueceram a quarentena, e começaram a sair. O governador, pela pressão dos empresários e do governo federal, começou a autorizar, dizendo que gradualmente, abertura de Igrejas, salões de beleza, restaurantes, shoppings e estabelecimentos comerciais. Havia casos, espetaculares, como no dia dos namorados, 12 de junho, a maioria dos amantes, faziam filas para entrar nos motéis, das grandes avenidas, da periferia de Manaus.

No entanto, muitos infectologistas e pesquisadores, alertavam à população uma segunda onda, que a pandemia recomeçaria com maior violência, a partir de agosto. Mas, foram poucos os que ficaram alarmados, a maioria, como sempre, pela ignorância ou por orgulho insano, somente acredita que a cloroquina os livraria desta pandemia. Ontem, 21 de julho, assistíamos à TV, o Jornal Nacional, em que relatou sobre a primeira dose da vacina contra o coronavírus feita pelo Instituto Butantan e o laboratório chinês Sinovac Biotech. E que para o fim do ano fabricariam 100 milhões de vacinas que serão distribuídas e aplicadas através do SUS. Uma esperança de alegria para a vida do Povo Brasileiro.

\section{Epílogo}

Segunda-feira, 9 de agosto de 2020. Transcendemos os 100 mil mortos por Covid-19. Ontem foi enterrado meu vizinho Celso Valadares, no Cemitério Municipal de Manaus, tinha 61 anos. Ele morreu de parada cardíaca, não sabemos, si é por complicação do coronavírus.

Os que não tem medo se expõe diariamente, se aglomeram nos restaurantes e bares, nas praias e nos shoppings, nas igrejas e escolas. Estes, talvez pela sua ignorância, não vêm o perigo desta pandemia.

No entanto, entendemos que o ser humano falhou, a escolha que fizemos de dominar a terra a fim de fruir sua floresta, seus mares, suas montanhas, seus espaços fez que destruíamos nosso planeta. Ao preferir o sistema capitalista que tem como objetivo o poder econômico e o desapreço pela vida fechamos as possibilidades de nossa própria existência. Faz quinze anos que apareceu o SARS, o primeiro corona-vírus no orbe, as grandes empresas de laboratórios de virologia não se dedicaram a estudar mais este fenômeno mundial porque as decisões dos capitalistas era pelo o lucro imediato, agora mesmo, os laboratórios estão correndo e fazendo um grande esforço para produzir uma vacina anticovid, porém não será de graças, os Estados Unidos (que tem uma população de 220 milhões de habitantes) já comprou, antecipadamente, 
todo o estoque da futura vacina feita pelo laboratório alemão Pfizer. A opção da estrutura capital/mercantilista nos está levando para a extinção do ser humano. A eleição do povo brasileiro fez que elegera um governo que despreze a sociedade em benefício de uma pequena elite, empresários, banqueiros e fazendeiros, apoiado por maus políticos e militares, grileiros e garimpeiros, maus policias e milicianos, os quais estão queimando nossas florestas, contaminando nossos rios, poluindo nossas cidades e exterminando os mais pobres. Desde quando começou este política genocida?

Não sei, mas eu continuo sobrevivendo. Eu buscado sempre dar-lhe um sentido a minha vida. A minha fugaz trajetória nesta terra sempre foi de ajudar o próximo, através de atos de desprendimento e generosidade, como não tinha tanto dinheiro, doava minha força, meu amor, meu tempo e estas tristes memórias nos tempos da pandemia.

\section{REFERÊNCIAS}

Camus, Albert. A peste / Albert Camus; tradução de Valerie Rumjanek Chaves. $-18^{\mathrm{a}}$ Ed. Rio de Janeiro: Record, 2009.

CONRAD, Joseph. O coração das trevas. Porto Alegre: L\&PM Pocket, 2004. $<$ https://www.sanarmed.com/linha-do-tempo-do-coronavirus-no-brasil $>$ Acesso em 17 agosto 2020. $<$ https://rd1.com.br/globo-estica-bbb-em-2020 $>$ Acesso em 17 de agosto 2020.

WHIFFEN, Thomas. O Nordeste Amazônico: Notas de alguns meses que passei entre tribos canibais. Rio Branco: Nepan, 2019.

Diário da Amazônia de Roger Casement / Edição de Angus Mitcheii; organização de Laura P. Z. Izarra e Mariana Bolfarine (coord.), Mail Marques de Azevedo e Maria Rita Drumond Viana. - São Paulo: Editora da Universidade de São Paulo, 2016. 